\title{
Chemical Composition of Ocimum americanum In Sudan
}

\author{
Ahmed Ali Mustafa*, Hatil Hashim El-kamali \\ Department of Botany, Faculty of Science and Technology, Omdurman Islamic University, Omdurman, \\ SUDAN
}

Received: 02 July,2019

Accepted: 09 Sept,2019

*Correspondence to:

Dr. Ahmed Ali Mustafa,

Email:

ahmad.ali11526@gmail.com

Copyright: () the author(s), publisher and licensee Indian Academy of Pharmacists. This is an open-access article distributed under the terms of the Creative Commons Attribution Non-Commercial License, which permits unrestricted non-commercial use, distribution, and reproduction in any medium, provided the original work is properly cited.

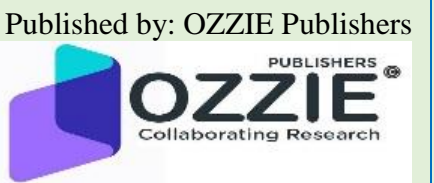

\section{Abstract}

Plants are one of the most important of medicines. Basil (Ocimum americanum) is one such plant which symbolize all that is extraordinary in nature because the entire whole plant has been used traditional medicine for household remedy against various human from antiquity. The genus O.americanum is known to include species accumulating essential oils. In this study the secondary metabolites of both flowers and leaves of O.americanum which occur in the central Sudan. The proximate analysis to samples showed the percentage of moisture content, total ash, crude fiber and fiber protein of the leave and flowers. The elemental analysis used Atomic Absorption Spectrometer (AAS) and flame emission for $\mathrm{Ca}, \mathrm{Fe}, \mathrm{Na}, \mathrm{K}, \mathrm{Mg}, \mathrm{Pb}$ and $\mathrm{Mn}$ plant under study. Preliminary phytochemical screening for carbohydrate, reducing sugars, monosaccharide, tannins, saponins, flavonoids, terpenoids, steroids, alkaloids, protein, amino acids and anthraquinones were performed. Using Gas Chromatography-Mass Spectrometer (GC-MS) analysis of n-hexane extracts, 22 nature compounds were recorder, most of the identified compounds in the extracts were terponoids in O.americanum monoterpenes were found to be7.29\% and sesquiterpenes (4.80\%)whereas alcohols and fatty acids were found to be the major constituents (1Octanol $39.09 \%$ and Octyl acetate $38.87 \%$ ) respectively. The results obtained showed that O.americanum is a good source of food and therapeutic agents which could be of use food and pharmaceutical industries information about the chemical composition of the oil could then be useful in the classification of this plant.

Keywords: Basil (Ocimum americanum); Chemical Composition; GC/MS; North Sudan

\section{INTRODUCTION}

According to WHO (World Health Organization), more than $80 \%$ of the world's population relies on traditional medicines for their primary health care needs. The medicinal value of spices, which include leaves, buds, bulbs, fruits, stem, rhizomes, bark and other plant parts, has been defined as plant substances from indigenous or exotic origin, aromatic or with strong taste, used to enhance the taste of foods. Herbs and spices have been used during the middle ages for flavoring, food preservation, and/or medicinal purposes. Only a small percentage of plants species have been investigated phytochemically and the fraction submitted to biological screening is even Smaller [1].

The diversity of the climate of Sudan is responsible for its very rich flora. In most of the studies carried out in the Sudan, scientists have, concentrated on known medicinal plants that are used locally. These plants are grouped into three categories: first medicinal plants that can be cultivated as field crops such as: Roselle (Karkadeh), second: Wild growing medical plant e.g.: Hargel, Colocynth, Hashab and Sunt. Third: imported medicinal plants e.g.: Dameseesa, and Chamomile [2]. Some compounds present in plant known as phytochemicals are valuable sources of food and medicine for the prevention of illness and maintenance of human health [3]. The family lamiaceae is widely distributed over the world. It comprises over 5,000 medicinal and aromatic plant species whose essential oils have multiple applications [4]-[5]. The genus Ocimum (Lamiaceae) comprises 160 species and is found throughout the tropical and sub-tropical regions of the world[6]. Several species of for the genus has commercial utility as a source of essential oil for the pharmaceutical, food, flavor and perfumery industries [7]. Ocimum americanum L. Linn commonly called as Ocimum canum belongs to the family lamiaceae (labiatae ) [8]. The plant is a 
pubescent erect much branched herb $15-60 \mathrm{~cm}$ high with sub-quandrangular striate branches [9]. Leaves are elliptic-lanceolate,entire ,glabrous and gland dotted strongly aromatic herb; branchlests puberulous , terete to four-angular [10]. Flowers are small, white, pink or purplish, in more or less closely set whorls in spiciform racemes [11]. Seeds are having nut lets with narrowly ellipsoid punctuate black [12].

The main chemical constituents are volatile oils include methyl cinnamate, methyl heptenone, methyl nonyl ketone, d-camphor, citral, Ocimin, methyl chavicol, linalool, nevadensin, salvigenin, beta-sitosterol, betulinic,ursolic oleanolic acids $m$ flavonoids pectolina rigenin -7-methyl ether and nevadensin,polys a ccharides composed of xylose , arabinose, rhamnose and galacturonic acids [13]. The main uses of Ocimum americanum are antimicrobial, antioxidant, antihelmintic and anti diabetic [14].

The study to investigation the proximate composition and element analysis of Ocimum americanum., to carry out preminary phytochemical screening of the organic constituents and characterize the chemical compounds for Ocimum americanum through Gas Chromatography-Mass Spectrometer (GC/MS)and hence to chemotaxonomically correlate them.

\section{Materials and Methods \\ Plant material}

The plant Ocimum americanum laeave and flowers was collected in the April 2017 from Karkog region in Sinnar state-Sudan the plant material was taxomically identified by prof. Hatil Hashim Elkamali University Omdurman Islamic Department of Botany, Dried plant 5day in the herbarium botany, after dried plant samples were the homogenized in pistil and mortar.

\section{Proximate composition}

Proximate composition was determined using the method described by AOAC [15] from the samples of investigated Ocimum americanum. The method was used to estimate moisture content, total ash, crude fibre and crude protein.

\section{Elemental Composition}

The $\mathrm{Na}$ and $\mathrm{K}$ was determined using flame emission photometer. The principle of this procedure relies on the fact that excitation of a metal in a flame gives rise to the emission of characteristics color. The intensity of the colour emitted by the excitation of any given atom is a property of the specific element and the concentration of that element while others $(\mathrm{Ca}, \mathrm{Fe}$, $\mathrm{Pb}, \mathrm{Mn}$ and $\mathrm{Zn}$ ) were analyzed by Atomic Absorption Spectrometer (AAS). The principle of this procedure relies on the absorption property of the elements. The vapors of the elements containing free atoms absorbs light having wave length as that which the atoms of the elements are capable of emitting.

\section{Phytochemical screening}

The phytochemical screening of plant sample was adopted from previous work [16].

\section{Preparation of Extract}

$50 \mathrm{gm}$ plant sample from Ocimum americanum were placed in $500 \mathrm{ml}$ conical flask and then $300 \mathrm{ml}$ $70 \%$ ethanol were added. The conical flask was placed in the water bath and was allowed to stand for 1 hour. The time was measured after boiling start (after appearance of the first bubble). The mixture (powder and ethanol) was filtered using filter paper while it is hot by using anther $500 \mathrm{ml}$ conical flask.

\section{Qualitative phytochemical Analysis:}

Phytochemical screening for the identification of major groups of chemical constituents using was carried out standard procedures [16-17]. The phytochemical components analyzed were, carbohydrates, reducing sugars, Monosacharides, Protein, Amino acids, Tannins, Saponins, Flavonoids, Terpenoids and/or Steroids, Alkaloids, Antharaquinones.

\section{Identification of the plant constituents by phytochemical tests:}

Ethanolic extract is subjected to various preliminary phytochemical analyses to test for present or absent of various phytoconstituents by the following tests.

\section{Test for Carbohydrates (Molischs Test):}

To the extract $1 \mathrm{ml}$ of the Molischs reagent was added then along the walls of the test tube carefully conc $\mathrm{H}_{2} \mathrm{SO}_{4}$ was added, formation of brown ring at the junction of tow liquids was observed.

\section{Test for reducing sugars (Fehling's Test):}

The extract was taken in a test tube, and the $1 \mathrm{ml}$ of the Fehling's solution (A and B) was added and 
boiled on the water bath. The solution was observed for the color change reaction.

\section{Test for Monosacharides (Barfoed's Test):}

To the extract in a test tube $1 \mathrm{ml}$ of barfoed's reagent was added and boiled on the water bath. The solution was observed for colour change reaction.

\section{Test for protein (Biuret Test):}

To $0.5 \mathrm{ml}$ of the extract $2 \mathrm{ml}$ of Biured Reagent was added and the reaction mixture observed for the formation of violet colour solution.

\section{Test for amino acids (Ninhydrin Test):}

To $0.5 \mathrm{ml}$ of the extract $2 \mathrm{ml}$ of the Ninhydrin was added and heated few minutes and the reaction mixture was observed for the deep blue paleyellow colouration.

\section{Test for tannins (Ferric chloride):}

$0.5 \mathrm{ml}$ of the extract was boiled with $10 \mathrm{ml}$ of distilled water in a test tube and then, few drops of $0.1 \%$ ferric chloride solution was added and the reaction mixture was observed for blue greenish black Colour change.

\section{Test for saponins (Frothing Test):}

$0.5 \mathrm{ml}$ the extract was added to $5 \mathrm{ml}$ of distilled water in test tube. The solution was shaken vigorously and observed for the stable persistent forth. Frothing was mixed with 3 drops of olive oil and shaken vigorously after which it was observed for the formation of an emulsion.

\section{Test for flavonoid:}

To $0.5 \mathrm{ml}$ of the extract $5 \mathrm{ml}$ of distilled water was added and then apiece of magnesium ribbon and $2 \mathrm{ml}$ of concentrated HCL was added. The reaction mixture was observed for the pink or red colour solution.

\section{Test for terpenoids and/or steroids:}

To $0.5 \mathrm{ml}$ each of the extract $2 \mathrm{ml}$ of chloroform was added and then $3 \mathrm{ml}$ of the concentration $\mathrm{H}_{2} \mathrm{SO}_{4}$ was carefully added to for a layer. A reddish brawn coluration of the interface indicated the presence of tepenoid and steroids.

\section{Test for alkaloid:}

Three different Test were used for the identification of alkaloids.

\section{Mayer Test:}

To $0.5 \mathrm{ml}$ of the extract $2 \mathrm{ml}$ of Mayer's reagent (K2HgI4) was added and the reaction mixture was observed for formation of creamy white precipitate.

\section{Wagnar test:}

To $0.5 \mathrm{ml}$ of the extract $2 \mathrm{ml}$ of wagner's reagent (dilute iodine solution) was added and the reaction mixture is observed for the formation of reddishbrown precipitate.

\section{Dragendorffs}

To $0.5 \mathrm{ml}$ of the extract $2 \mathrm{ml}$ of Dragendorff's reagent was added, the reddish-brown precipitate observed in the reaction mixure indicates the presence of alkaloids.

\section{Test for anthraquinones (Borntragor's Test) :}

To $0.5 \mathrm{ml}$ of the extract $5-10 \mathrm{ml}$ dilute HCL was added and boiled on water bath for 10 minutes and filtered then the filtrate was extracted with carbon tetra chloride and the equal amount of ammonia was added, after shaking the reaction mixture was observed for the formation of pink red colour in the ammonia layer.

\section{Gas Chromatography Mass Spectrometer (GC/MS)}

GC was equipped with MS (Shimatzo QP 2010 GC/MS Instrument equipped with reference libraries). Packed material for column were 50\% phenyl and 50\% methyl polysiloscane, column length 30 meter, diameter $0.025 \mathrm{~mm}$, the flow rate of helium as carrying gas was $1 \mathrm{ml} / \mathrm{min}$. The temperature of program consisted of 60-270 C, at rate of $4 \mathrm{C} / \mathrm{min}$. MS were taken at ionization voltage $70 \mathrm{UV}$. Library search was carried out using Wiley GC/MS library.

\section{Identification of isolated compounds}

The individual identifications were made by the comparison of fragmentation patterns with those found in the library of the mass spectrometer.

\section{Result and Discussion}

The result of proximate composition (Table 1) shows that the moisture content of the sample was flowers $(5.53 \pm 0.01)$ and leave $(5.5 \pm 0.1)$. This is 
expected since the sample has been subjected to drying for five days to reduce the moisture content. High moisture content is an index of spoilage. The result also shows that the leaves of $O$. americanum contain higher level of ash content $(19.09 \pm 0.01 \%)$ than flowers $(8.87 \pm 0.05 \%)$. The ash content is a reflection of its mineral content. The ash content of the leaves compared to the flowers presents that the minerals are more concentrated in the leaves than in the flowers. The result also shows that the flowers have more crude fibre content with value $(29.23 \pm 0.02 \%)$ the leaves with value $(13.8 \pm 0.01 \%)$. Crude fibre provides roughages that aids digestion and reduces the accumulation of carcinogen in the body [18]. The protein content was flowers $(10.15 \pm 0.9)$ and leave $(18.43 \pm 0.31)$ the high protein content buttressed the use of the plant leave as flavor soup and spice meat. The basic function of protein in nutrition is to supply adequate amounts of required amino acids [19]. Protein deficiency causes growth retardation, muscle wasting, and abnormal swelling of the belly and collection of fluids in the body [20]. The concentration of calcium, iron, sodium, potassium, lead, manganese and zinc in plant sample obtained from the Ocimum americanum was performed using Atomic absorption (Table 2).

The minerals are very important in human nutrition. The results of the calcium content shows that the aerial parts of $O$. americanum (41.01 $\mathrm{mg} / 100 \mathrm{mg}$ ). Calcium is required in the body for human growth of bones and teeth [18]. Calcium (Ca) and potassium $(\mathrm{K})$ are reported to be responsible for the repair of worn out cells, strong bones and teeth, building of red blood cells and for body mechanisms [21]. Also, $\mathrm{Ca}$ and $\mathrm{K}$ are essential for disease prevention and control and may therefore contribute to the medicinal influences of the plant [3]. Potassium (K) is needed for growth and transmission of the nervous system to transmit messages as well as regulating the contractions of muscles [22]. The results of sodium show $(1.162 \mathrm{mg} / 100 \mathrm{~g})$ while the potassium content higher level of the (18.200) $\mathrm{mg} / 100 \mathrm{mg}$. The result of iron content shows the $(1.596 \mathrm{mg} / 100 \mathrm{~g})$. The result of $\mathrm{Pb}$ shows that this element was not found. The result obtained shows the contain 0.122 $\mathrm{mg} / 100 \mathrm{~g} \mathrm{Zn}$. The concentration of calcium, iron, sodium, potassium, lead, manganese and zinc in plant sample obtained from the Ocimum americanum was performed using Atomic absorption (Table 2).

The minerals are very important in human nutrition. The results of the calcium content shows that the aerial parts of $O$. americanum (41.01 $\mathrm{mg} / 100 \mathrm{mg}$ ). Calcium is required in the body for human growth of bones and teeth [18]. Calcium (Ca) and potassium (K) are reported to be responsible for the repair of worn out cells, strong bones and teeth, building of red blood cells and for body mechanisms [21]. Also, $\mathrm{Ca}$ and $\mathrm{K}$ are essential for disease prevention and control and may therefore contribute to the medicinal influences of the plant [3]. Potassium (K) is needed for growth and transmission of the nervous system to transmit messages as well as regulating the contractions of muscles [22]. The results of sodium $162 \mathrm{mg} / 100 \mathrm{~g}$ ) while the potassium content shows (1. higher level of the (18.200) $\mathrm{mg} / 100 \mathrm{mg}$. The result of iron content shows the $(1.596 \mathrm{mg} / 100 \mathrm{~g})$. The result of $\mathrm{Pb}$ shows that this element was not found. The result obtained shows the contain $0.122 \mathrm{mg} / 100 \mathrm{~g} \mathrm{Zn}$.

Many phytochemicals found in plants are either the product of plant metabolism or synthesized for defence purposes. The phytochemicals are either useful or toxic to human body [23]. Saponins are steroidal glycosides with foaming characteristics and bitter taste that have beneficial effect on the blood cholesterol levels, fight cancer and help in health and the stimulation of immune system [24]. Saponins have hemolytic properties and are used as starting materials for the synthesis of steroidal drugs like corticosteroids, the sex hormone stimulants and contraceptives [3]. They are also used for the treatment of viral diseases [18]. Tannins are stringent bitter plant polyphenols that bind, precipitate and shrink proteins and various organic compounds. Tannins are known to have anti-viral, anti-tumor, anti-inflammatory and healing properties on wounds, kidney etc [17]-[18]. The Ocimum americanum extract, which was found to contain saponins, tannins, could be useful for medicine al purpose.

$\mathrm{N}$-Hexane extract of O.americanum aerial parts was analyzed through GC/MS (Tables 4 and 5). A 
total of twenty two compounds were identified from O.americanum aerial parts. Monoterpenes were found to be $7.94 \%$ and sesquiterpenes
(4.80\%) whereas alcohols and fatty acids were found to be the major constituents (1-octanol $39.09 \%$ and Octyl acetate $38.87 \%$ ), respectively.

Table 1. Proximate composition of the flowers and leaves of the Ocimum americanu.L. :

\begin{tabular}{|c|c|c|c|c|}
\hline Part use & Moisture content & Total ash & Crude fiber & Crude protein \\
\hline Flowers & $5.53 \pm 0.1$ & $8.87 \pm 0.05$ & $29.23 \pm 0.2$ & $10.15 \pm 0.9$ \\
\hline Leaves & $5.5 \pm 0.1$ & $19.09 \pm 0.1$ & $13.8 \pm 0.1$ & $18.43 \pm 0.31$ \\
\hline
\end{tabular}

Mean \pm Standard deviation of triplicate determinations.

Table 2. Element Composition (mg/100g) of Candidate Ocimum americanum using Atomic Absoption Spectrometer (AAS)

\begin{tabular}{|c|c|c|c|c|c|c|c|}
\hline Minerals & $\mathrm{Ca}$ & $\mathrm{Fe}$ & $\mathrm{Na}$ & $\mathrm{K}$ & $\mathrm{Pb}$ & $\mathrm{Mn}$ & $\mathrm{Zn}$ \\
\hline $\mathrm{Mg} / 100 \mathrm{~g}$ & 41.01 & 1.596 & 1.162 & 18.200 & $\mathrm{ND}$ & 0.112 & 0.122 \\
\hline
\end{tabular}

Table 3. phytochemical screening of ethanolic extracts of Ocimum americanum

\begin{tabular}{|c|c|c|c|}
\hline Phytochemical screening & Regented use & \multicolumn{2}{c|}{ Ocimum americanu } \\
& & Leaves & Flowers \\
\hline Carbohydrates & Moliches & + & + \\
\hline Reducing sugars & Flehlings & + & + \\
\hline Monosaccharides & Barfoeds & - & + \\
\hline Proteins & Biuret & - & + \\
\hline Amino acids & Ninhydrin & + & + \\
\hline Tannins & Ferric Chloride & + & + \\
\hline Saponins & Frothing & + & + \\
\hline Flavonoids & magnesium + HCL & + & - \\
\hline Terpenoids and steroids & Chloroform+H ${ }_{2} \mathrm{SO}_{4}$ con & + & + \\
\hline Alkaloids & Mayers & & - \\
\hline Anthraquinones & Wagners & - & + \\
\hline
\end{tabular}

Key $:+=$ present ; - = Absent

Table 4. Chemical composition of n-hexane extract of Ocimum americanum:

\begin{tabular}{|c|c|c|c|c|}
\hline NO & Compounds & RT & $\%$ & Formula \\
\hline 1 & $\begin{array}{c}\text { 3-hydroxy-3-methyl pentanoic } \\
\text { acid }\end{array}$ & 4.711 & 0.91 & $\mathrm{C}_{6} \mathrm{H}_{12} \mathrm{O}_{3}$ \\
\hline 2 & $\alpha$-pinene & 4.868 & 0.48 & $\mathrm{C}_{10} \mathrm{H}_{16}$ \\
\hline 3 & Hydroperoxide,1-methyl pentyl & 5.271 & 0.21 & $\mathrm{C}_{6} \mathrm{H}_{14} \mathrm{O}_{2}$ \\
\hline 4 & 3-penten-2-one ,4-methyl & 5.523 & 2.80 & $\mathrm{C}_{6} \mathrm{H}_{10} \mathrm{O}$ \\
\hline 5 & Octanal & 6.135 & 1.23 & $\mathrm{C}_{8} \mathrm{H}_{16} \mathrm{O}$ \\
\hline 6 & Acetic acid, hexyl ester & 6.323 & 0.41 & $\mathrm{C}_{8} \mathrm{H}_{16} \mathrm{O}_{2}$ \\
\hline 7 & 3-hepten-2-one & 6.528 & 0.22 & $\mathrm{C}_{7} \mathrm{H}_{12} \mathrm{O}$ \\
\hline 8 & Cyclohexane,nitro & 7.053 & 0.32 & $\mathrm{C}_{6} \mathrm{H}_{11} \mathrm{NO}_{2}$ \\
\hline 9 & 1-Octanol & 7.537 & 39.09 & $\mathrm{C}_{8} \mathrm{H}_{18} \mathrm{O}$ \\
\hline 10 & Linalool & 8.162 & 0.65 & $\mathrm{C}_{10} \mathrm{H}_{18} \mathrm{O}$ \\
\hline 11 & Octyl acetate & 10.485 & 38.87 & $\mathrm{C}_{10} \mathrm{H}_{20} \mathrm{O}_{2}$ \\
\hline 12 & Neral & 11.185 & 2.43 & $\mathrm{C}_{10} \mathrm{H}_{16} \mathrm{O}$ \\
\hline 13 & Geranial & 4.792 & $\mathrm{C}_{10} \mathrm{H}_{16} \mathrm{O}$ \\
\hline
\end{tabular}




\begin{tabular}{|c|c|c|c|c|}
\hline 14 & (E)- $\beta$-Famesene & 15.413 & 1.09 & $\mathrm{C}_{15} \mathrm{H}_{24}$ \\
\hline 15 & Humulene & 15.540 & 0.91 & $\mathrm{C}_{15} \mathrm{H}_{24}$ \\
\hline 16 & $\beta$-Bisaibolene & 16.448 & 1.97 & $\mathrm{C}_{15} \mathrm{H}_{24}$ \\
\hline 17 & $\begin{array}{c}3,7,11,15-\text { Tetramethyl-2- } \\
\text { hexadecene }\end{array}$ & 21.513 & 0.21 & $\mathrm{C}_{20} \mathrm{H}_{40}$ \\
\hline 18 & $\begin{array}{c}\text { 2-hexadecen-1-ol, 3,7,11,15- } \\
\text { Tetramethyl }\end{array}$ & 21.586 & 1.54 & $\mathrm{C}_{20} \mathrm{H}_{40} \mathrm{O}$ \\
\hline 19 & 2-Hexyl-1-decanol & 21.670 & 0.51 & $\mathrm{C}_{16} \mathrm{H}_{34} \mathrm{O}$ \\
\hline 20 & 2-methyl-7-octadecyne & 21.907 & 0.32 & $\mathrm{C}_{19} \mathrm{H}_{36}$ \\
\hline 21 & 9-Eicosyne & 22.140 & 0.58 & $\mathrm{C}_{20} \mathrm{H}_{38}$ \\
\hline 22 & Phytol & 24.795 & 0.78 & $\mathrm{C}_{20} \mathrm{H}_{40} \mathrm{O}$ \\
\hline
\end{tabular}

Table 5. Statistics chemical classes of n-hexane extract of O.americanum :

\begin{tabular}{|c|c|c|}
\hline Compounds & No of compounds & Concentration\% \\
\hline Total monoterpene & 3 & 7.29 \\
\hline Total sequiterpene & 5 & 4.80 \\
\hline $\begin{array}{c}\text { Total oxygenated } \\
\text { sesquiterpenes }\end{array}$ & 1 & 0.51 \\
\hline Alkene derivative & 2 & 1.75 \\
\hline Cyclic diterpene alcohol & 1 & 0.78 \\
\hline Fatty acids & 1 & 38.87 \\
\hline Ketone & 2 & 1.45 \\
\hline Ester & 1 & 0.21 \\
\hline Alcohol & 1 & 39.74 \\
\hline Carboxylic acid & 1 & 0.41 \\
\hline Hydrocarbone alkyne & 1 & 2.80 \\
\hline Other & 2 & 1.23 \\
\hline Total & 22 & 99.91 \\
\hline
\end{tabular}

\section{Conclusion}

The result of proximate composition and element analysis it is quite interesting that Ocimum americanum $\mathrm{Ca}$ and $\mathrm{K}$ higher. The findings of this study shows that the contained Ocimum americanum 1-Octanol and Octyl acetate

\section{References}

1. Harsha N, Sridevi V, Chandana LMVV, Rani KN, Vani DS. Phytochemical Analysis of Some Selected Spices. Int J Innovative Res Science, Engineering and Technology. 2013;2(11):661921.

2. Sayadat ET. Mohammed, Sudan Journal of Basic sciences. Published by: Publication UnitSudan Institute for Natural sciences. 2002.

3. Aliyu AB; Musa AM, Oshaniyi JA. Phytochemical Analysis and Mineral Composition Analysis of Some Medicinal Plants of Northern Nigeria. Nigerian J Pharm Sci.2008;7(1):119.

4. Piras A Goncalves $\mathrm{Mj}$ Alvse, Flaconieri D, Poredda S, Maxia A, salgueiro L. Ocimam tenuifloram $L$. and Ocimam basilicum two
chemotaxonomy.The Ocimum americanum would serve as good sources of pharmaceutical drugs. The main identified constituents in Ocimum americanum n-hexane extract was 1-Octanol (39.09\%), Octyl acetate (38.87\%), Geranial (4.47\%) and 3-penten-2-one,4-mehyl (2.80\%).

spices of lamiaceae family with bioactive essential oils Industrial crops and products. 2018;113: 89- 97.

5. Sakkas H, Papadopulou C. Antimicrobial activity of basil oregano and thyme essential oil. J Microbiol Biotech. 2017;27(3):429-438.

6. Sobti SN, Pushpangandan P. In Cultivation and utilization of Aromatic plants; Atal, C.K., Kaper BM, Ed.; Research Lab; Jammu-Tawi India. 1982;3:457-472.

7. Guenther E. In the Essential oils; R. Kriegar; New York. Vol 1, 1972.

8. Wealth of India Raw materials CSIR, New Delhi 79-81.

9. Rastogi RP, Metrotra BN, Compendinun of Indian Medicinal plants, 1980-1984:CDRI, 
Lucknow and publications and Information Directorate, New Delhi,(1993):454-456.

10. Joshi SG, Medicinal plants Oxford and IBH Publishing Co.pvt, New Delhi2000,p. 227.

11. Bhattacharjee SK, Hand book of Medicinal plants , Edn 5, Pointer Publishers, Jaipur: 40241.

12. Ravindra Sharma, Medicinal plants of India an Encyclopedia Daya publishing house, New Delhi,2003, p 174.

13. Chopra RN, Nayar SL, Chopra IC, Glossary of Indian Medicinal plants, Edn 1, 1956:178.

14. Khare CP, Indian Medicinal plants And illustrated Dictionary, Springer, New Delhi, 2007:444.

15. AOAC (2004) Association of Official Analytic Chemist. Official method of analysis. Washinton,D.C.,14 th. ed Math, R. G., Velu, V., Nagender, A., and Rao, D. G. (2004). Effect of frying conditions on moisture, fat, and density of papad. Journal of Food Engineering, 64(4), 429-434.

16. Sofowura A, Medicinal plants and traditional Medicine in Africa $3^{\text {th }}$ Edition spectrum Books Ltd Ibadan, Nigeria. 2008;23-25.

17. Harborne JB. Phytochemical methods, London. Chapman and Hall, Ltd, 1973;49-188.
18. Robinson C.H. Mineral Elements. In: Fundamentals of natural nutrition, new York: McMilian Publication, Thd Ed. 1978.

19. Pugalenthi M, Vadivel V, Gurumoorthi $P$, Janardhanan K. Comparative nutritional evaluation of little-known legumes, Tamarindus indica, Erythrina indica and Sesbania bispinosa. Tropical and Subtropical Agroecosystems. 2004;4(3):107-123.

20. Zarkada CG, Voldeng HD, Determination of the protein Quality of three new Northern adapted cultivars of common and micro types soya beans by amino acids analysis. J Agricultural Food Chemistry. 1997;45:11611168.

21. Amokaha RA; Ubwa ST; Otokpa M, Shenga G. Phytochemical Screening of Danta Stramo niumlinn (Silanacease) Seeds. J Chemical Society of Nigeria. 2002;27(1):105-107.

22. Sale JF, Maji JO; The Phytochemical and Antimicrobial Screening of Honey Based (Ilesha Wonder Drug). Proceedings of the 1st National Conference of the Faculty of Natural.2006.

23. Trease GE, Evans WC; A Textbook of Pharmacognosy. 13th Edition, Bailere Tindau, London, 1989; 315 - 544.

24. United State National Nutritional Data (USNND, 2010). 